\title{
THE GOLGI APPARATUS
}

PERSONAL OBSERVATIONS AND A REVIEW OF THE LITERATURE

ALWIN M. PAPPENHEIMER

From the Department of Pathology, College of Physicians and Surgeons, Columbia University; and from the Marine Biological Laboratory, Woods Hole, Mass.

TWENTY-TWO FIGURES

CONTENTS

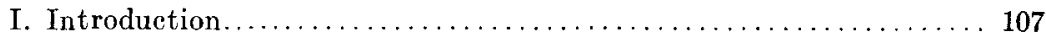

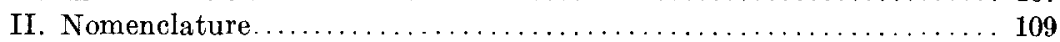

III. Technique....................................... 110

IV. The occurrence of the Golgi apparatus in various types of tissue cells:

1. Nervous tissue.................................. 112

2. Non-mervous tissue.............................. 114

a. Epithelial cells.......................... 114

b. Connective tissue cells, cartilage, osteoblasts, odonto-

blasts, striated muscle cells................... 127

c. Gonads..................................... 130

V. The Golgi apparatus in the cells of embryos................. 132

VI. The Golgi apparatus in protozoa...................... 133

VII. The Golgi apparatus under pathological conditions............. 133

VIII. General considerations. Relation to centrosomes. Polarity. Physical nature of the structures. Holmgren's trophospongium theory. . 135

IX. Conclusions ................................... 138

\section{INTRODUCTION}

It is rather extraordinary that there should be within every cell a structure as conspicuous as the nucleus, and sometimes surpassing it in size, the meaning of which is utterly obscure. One at least of the functions of the nucleus-its rôle in heredityis known to us. We have fairly definite ideas as to the rôle of the centrosomes, and theories aplenty as to the part played by mitochondrial structures, and other types of granules. But as regards the structure to which Golgi has given the name 'Apparato reticolare interno,' we have learned only its appearance, its distribution in different types of cells, and its behavior dur- 
ing cell division. One of the most recent papers on the subjectthat of Kolster (102)--ends with the statement "These structures undoubtedly have a special significance, but we are ignorant of it."

The credit for the discovery of this intracellular organelleif such it be-undoubtedly belongs to Golgi, and a large part of the work, including the working out of a fairly easy and satisfactory technique for its demonstration - has been done by Golgi himself, and by his pupils and co-workers, Veratti, Perroncito, Pensa, Negri, Gemelli, Brugnatelli and others. A number of papers dealing with the same structures have been published by Ramon-y-Cajal, who, indeed claims priority for their discovery over Golgi, and by his pupils, Sanchez, Fananas, Tello and others. Nussbaum, in Prague, has inspired a series of papers by his pupils (Weigl, Polyescynski, Bialschowska and Kulikowska) dealing chiefly with the appearance of the Golgi apparatus in the ganglion cells of invertebrates. Important papers have been published by $v$. Bergen, Deineke and by Kopsch, who discovered a new and very simple method for demonstrating the apparatus. The best and most exhaustive general review on the subject is that of Duesberg (48), before the XXVIII Meeting of the Anatomische Gesellschaft at Innsbruck in 1914, and Cajal (31) in his most recent publication ('15) which was not available at the time this study was begun, has contributed a most interesting critical survey of the entire field, and added many new observations.

A whole chapter--largely controversial-is that contributed by Holmgren, whose views and their bearing I shall take up later. In this country only Bensley and Cowdry have made contributions to the subject.

In reviewing the literature of the subject I found that but few workers, with the exception of Cajal and his pupils, had attempted to study the behavior of the Golgi apparatus under experimental conditions. I planned, therefore, to follow the modifications of the structure in the epithelial cells of the rat kidney, which might be produced by autolytic changes, secretory phases and toxic agents. The choice of material was unfortunate. The Golgi apparatus of the cells of the renal tubules 
proved to be so atypical and variable in form that it was difficult to draw inferences from variations seen under experimental conditions. One was further handicapped by the difficulties and capriciousness of the impregnation method, as applied to this organ.

In attempting to control the technique many other tissues were studied, and insofar as the observations made differ from those of previous workers, they are given below.

Although I was unsuccessful in the main purpose of my study, it seemed that it might be useful at this time to collate the widely scattered and rather inaccessible literature, and to record my personal observations, insofar as they supplement or are at variance with those of other workers in this field.

\section{NOMENCLATURE}

Golgi (61), in his original communication before the Med. Chir. Society of Pavia in 1898, suggested the term 'Apparato reticolare interno,' and this term has naturally been adopted by all the Italian workers. Kopsch (103) proposed the term 'Binnennetz' as the German equivalent, but both of these designations are open to the objection that the structures do not appear in all types of cells, nor under all conditions, as a closed net. Ballowitz (4) in 1899 described a basket-like structure about the centrosomes of the cells of Descemet's membrane, and suggested for it the name 'Centrophormia.' Later he recognized the homology of the 'Centrophormia' with the Golgi apparatus, and the term has not come into common use. The 'Nebenkern' of Platner (145) and la Valette St. George (106), and the 'Zentralkapsel' of Heidenhain (68) in the sperm cells have been considered by some as related to or identical with the structures demonstrated by the Golgi technique. The terms, however, are not sufficiently inclusive to apply to the structures described by Golgi. Ramon-y-Cajal and his school who agreed with Holmgren in regarding the apparatus as canalicular in nature-referred to it in their earlier publications as the Holmgren-Golgi apparatus. In his latest review, however, Cajal (31) recognizes the very doubtful identity of many of the structures described by Holm- 
gren with those brought out by the Silver methods, and therefore refers to them more justly as the Golgi apparatus. Many of the German workers speak of the Golgi-Kopsch net or apparatus.

Holmgren (90), who believes in the identity of the canaliculi described by him, with the structures put in evidence by the silver impregnation methods, uses the term 'Trophospongium.' Cowdry (42) and Bensley (14) speak of 'canalicular apparatus.'

None of these terms appear to be entirely satisfactory. I shall, therefore, refer to the structures simply as the Golgi apparatus.

\section{TECHNIQUE}

The earliest studies of Golgi were made with a modification of his well-known silver chromate method. This gave capricious and inconstant results. Veratti introduced a modification, the essential feature of which was a fixation in osmium platinic chlorid mixture. Kopsch (103) in 1902 showed that prolonged immersion in 2 per cent osmic acid would demonstrate structures identical with those described by Golgi.

The two methods now most commonly used are those of Golgi (66) and of Cajal (30), and, for the convenience of those to whom the original articles are not accessible, they are given here:

The Golgi method is as follows:

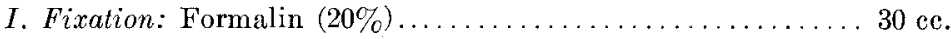

Saturated solution arsenious acid $(1 \%) \ldots \ldots \ldots 30 \mathrm{cc}$.

Alcohol $(97 \%) \ldots \ldots \ldots \ldots \ldots \ldots \ldots \ldots \ldots \ldots . \ldots \ldots$ ce.

6 to 24 hours.

II. Silver nitrate $1 \% \ldots \ldots \ldots \ldots \ldots \ldots \ldots 1$ hour to several days

III. Development: Hydroquinone........... $20 \mathrm{gm}$.

Sodium Sulphite........... $1 \mathrm{gm}$.

$\left.\begin{array}{l}\text { Formalin................... } 20 \mathrm{cc} . \\ \text { Distilled water ad } 1000 \mathrm{cc} .\end{array}\right\} 2$ to 3 hours

Wash in distilled water, dehydrate rapidly and embed

IV. Toning: in paraffin or cclloidin.

Solution 'A' Sodium hyposulphite.............. $30 \mathrm{gm}$.

Ammonium Sulphocyanate............. $30 \mathrm{gm}$.

Distilled water.................... $1000 \mathrm{cc}$.

Solution 'B' Gold chloride...................... $1 \%$

Use equal parts of 'A' and ' $B$ '. Tone to grey tone. 
Veratti has devised the following procedure for ridding the preparation of silver precipitate after toning:

' $A$ '-Repeated washing in distilled water.

'B'-Rapid passage through following solutions:

(1) Potassium permanganate $-0.5 \mathrm{gm}$.

Sulphuric acid-1.0 ce.

Distilled water-1000 ec.

(2) Oxalic acid-1\%

Wash in distilled water. Counterstain with alum earmine.

The latest Cajal method differs from the Golgi chiefly in the use of uranium nitrate in place of the arsenious acid in fixation. It is given as follows:

I. Fixation: Uranium nitrate-1 gm.

Formol-15 cc. 9 to 11 hours

II. Wash quickly

Distilled water-100 cc.

III. Silver nitrate-1.5\%-30 to 40 hours

IV. Wash quickly

$V$. Reduce in

Hydroquinone $-2 \mathrm{gm}$.

Formol-6 gm.

Distilled water-100 ce.

Add anhydrous sodium sulphite- $-0.15-0.25 \mathrm{gm}$. so that solution has a yellow color.

$V I$. Dehydrate and embed in paraffin.

VII. Toning:

'A' Sodium hyposulphite $-3 \mathrm{gm}$.

Ammonium sulphocyanate- $-3 \mathrm{gm}$.

Distilled water-100 ec.

'B' Gold chloride-1\%

Use equal parts.

The addition of $30 \mathrm{cc}$. of ethyl or methyl alcohol to the fixative is recommended by Cajal ('15), as advantageous in the case of nervous tissue.

As counterstain I have found a dilute Giemsa solution to give the clearest pictures. A 1 per cent methyl-green solution may also be used, and it has been found possible to combine also the Altmann mitochondrial stain, as modified by Bensley. ${ }^{15}$

The removal of the silver precipitate with permanganate and oxalic acid must be very carefully controlled, as it is easy to bring about a complete decolorization of the Golgi apparatus as well. 
Cajal and others have obtained the most constant results in the tissues of young animals. Because of the rapid occurrence of autolytic changes little confidence can be placed in the results obtained with tissues from human autopsies.

Both the Golgi and Cajal methods are exceedingly capricious; the impregnation is rarely uniform throughout the entire block.

The most delicate and important step in these photographic processes, according to several workers, is the initial time of fixation. Each type of cell has its optimum time of fixation, which must be determined experimentally. In many cells, however, as in the lymphocytes, spermatic cells, glomeruli of the kidney, this appears to vary within wide limits. That, at least, has been my experience, and I have obtained identical pictures with fixation varying from 2 to 12 hours.

The technique most recently advocated by Holmgren for demonstrating his Trophospongium is a fixation in trichlorlactic acid (6 per cent) and staining in a freshly prepared resorcinfuchsin solution. The 'canals' take a purplish black color. Holmgren also gives methods which show the canals as colorless structures upon a stained background.

IV. THE OCCURRENCF OF TIIE GOLGI APPARATUS IN VARIOUS TYPES OF TISSUE CELIS

\section{Nervous tissue}

The first clear description of the structures is that of Golgi in $1898(61,62)$, in the spinal ganglion cells of Strix flammea (Barn-owl); in the same year, he made similar observations upon the spinal ganglion cells of Mammalia; Veratti in 1898 found the same sort of structure in sympathetic ganglion cells. Since these early papers, the Golgi apparatus has been found to be present in many other types of nerve cells-the anterior horn cells (Golgi (66), Cajal (31)), the pyramidal cells of the cortex (Golgi (65), Legendre (107), Collin and Lueien (37), Soukhanoff (167), Cajal (31)), the Purkinje cells and other nerve cells of the cerebellar cortex (Golgi (66), Cajal (31)), of the olfactory lobe (Cajal (28)), the ganglion cells of insects 
(Bialkowska and Kulikowska (19)), of the leech and earthworm (Bialkowska and Kulikowska), Crustacea (Jawarowsky (98), Monti (127), Polenzynsky (146), of cephalopods (Weigl (180)).

The apparatus reaches its greatest complexity and size in the spinal ganglion cells of vertebrates, and these have, therefore, been a favorite object of study. In adult vertebrates there is shown by the silver or osmic methods, a definite network of solid, tortuous varicose fibrils, which vary in thickness with different species. This network may completely or partially surround the nucleus and may be in contact with it in places. Where the threads cross or interlace, there are often nodular varicosities. In some species there is a sort of lobulation, into three or four partially separated skeins, and individual filaments may be given off from the main mass, and apparently end freely in the cytoplasm. In all cases the peripheral zone of eytoplasm is left free; at no point does the network, or any of its branches reach the surface.

Monti (127), in the ganglion cells of invertebrates (crustacea, arthropods and cephalopods) found a simple apparatus in the form of curved filaments, often bifurcating or anastomosing, but not forming a closed reticulum. V. Bergen (10), working with the Kopsch osmium method, upon the spinal ganglion cells of the hedgehog, cat, rabbit, rat, mouse, and hen, found that not all the cells showed a complete reticulum as described by Golgi, some containing only short filaments, rows of granules or ring forms. Some of the filaments contained a central clear space, and these he interpreted as degeneration forms. This variation in the appearance of the apparatus in different cells in the same preparation v. Bergen interprets as indicating the transitory nature of these structures. He suggests that they are developed from granules, which range themselves into filaments, form more complex networks, and finally undergo central liquefaction with the formation of canaliculi. Other recent workers, however, using the newer methods of Golgi and Cajal have not confirmed v. Bergen's theory, and ascribe the variations to defective impregnation. 
Cajal (31), like v. Bergen, notes variation (or 'modalities') in the type of net occurring in ganglion cells of the same order and size. He strongly rejects the idea that these variations are due to irregularities in impregnation, since they may be found in adjoining cells at similar depths from the surface.

The question has arisen as to whether the Golgi apparatus is identical with any of the other known cytoplasmic constituents of the nerve cell-namely, the neurofibrillae, the Nissl substance or the mitochondria. It seems quite certain, in spite of occasional statements to the contrary, that the Golgi net is unrelated to any of these structures. The net is not continued into the cell processes, as are the neurofibrillae, and the fibers of the net are much thicker and more varicose. By combining Kopsch's method with Bensley's aniline-fuchsin toluidin-blue stain, as Cowdry (42) has done, the Golgi net, Nissl bodies and mitochondria may all be stained in the same cells, and their independence of one another made obvious. It seems hardly worth while to go further into this cliscussion.

\section{Tissue cells other than nerve cells}

a. Epithelial cells. The presence of a Golgi apparatus was first demonstrated in the squamous epithelial cells of Ammocoetes (Lamprey eel) by Marenghi (120) in 1903, and in Lumbricus by Ramon-y-Cajal in the same year. Since then it has been found in the corneal epithelium by Barinetti (6) and by Deinecke (47). The net is present in all layers. In the superficial cells the net becomes looser, and often almost entirely surrounds the nucleus, whereas in the rete mucosum, it lies at the superficial pole of the nucleus, and in the cells near the surface, only granular bodies are found. This change, therefore, accompanies the aging of the cells, and is characteristic not only of corneal epithelium, but also of skin, oesophageal mucosa, the epidermis of the ducks bill (Deinecke, Kolmer (100)). Some of our preparations of the mucosa of the renal pelvis show a similar differentiation.

A Golgi net has been found also in cells of the epidermal appendages and glands--in the lachrymal gland by Ancona (3) 
and in the sweat and sebaceous glands by v. Bergen (10), by Bizzozero and Bottisella (21) (who picture a net surrounding the nucleus, and also, incidentally, could not demonstrate it in the epidermal cells), and by Tello (172).

Since the first paper of Ballowitz (4) in 1898, a net has been found in the single layered epithelial cells of Descemet's membrane by Totsuka (174), Zawarzin (184), and by Deinecke (47). The net in these cells is of special interest because it very clearly lies in relation to the centrosomes, and because it was discovered independently of Golgi's work by Ballowitz. Deinecke in these cells, also, made a careful study of the behaviour of the net during mitosis.

Numerous observations confirm the presence of a Golgi apparatus in the glandular cells of the gastro-intestinal tract. Thus Ramon-y-Cajal ('03) found it in the intestinal epithelium of lumbricus, and of the guinea pig (27); v. Bergen (10) in the chief cells of the fungus region ('04), Golgi (67) in the gastric and intestinal mucosa of frogs, birds and mammals, in the glands of Brunner and of Lieberkuhn ('09); d'Agata (43) in the gastric epithelium of triton ('10) and in the gall-bladder epithelium of the guinea pig (44); Weigl (180) and Kolmer (100) in the gastric and intestinal mucosa of various vertebrates; Kolster (102) in the chief and parietal. cells of the fundus, in the pylorus and in the cells of Brunner glands ('13).

Kolster has made several interesting observations on the behaviour of the Golgi apparatus in the gastric cells. He found that when the chief cells were successfully impregnated the parietal cells were not. He also showed that, by using the original Golgi silver chromate method, it was possible to impregnate a system of endocellular excretory canals in the chief cells of the fundus, and that these differed, both in their topography and in their form from the true Golgi apparatus. He noticed also in the pyloric gland cells that the appearance of the net varied with different phases of secretion. In the resting cells the net was quite dense, the meshes small, the form of the whole mass spherical; while in secreting cells, the net was rare- 
fied (aufgelockert), elongated and extended to the basal portion of the cell, in close contact with the flattened nucleus.

Cajal (31) also describes in great detail a cycle of changes corresponding to different secretory phases in the goblet cells of the alimentary tract. The Golgi apparatus during the earlier phases undergoes an increase in size, later the argentophile substance becomes dispersed amongst the globules of secretion, and completely disintegrates--not as Kolster (102) believes, becoming merely compressed against the nucleus at the base of the cell.

The inferences which Cajal draws as to the functional significance of these cyclical changes, will be discussed later.

Before having access to Cajal's paper, I had independently observed similar alterations in the mucous glands of the larynx (figs. 1, 2, 3). It seems to be quite clear that the net, which is more distinct and well-formed in cells during the inactive stage, becomes broken up and distributed amongst the globules of mucus in those cells which are actively secreting. In the course of this process, there appears to occur a real quantitative decrease in the amount of the argentophile substance not to be explained merely by its mechanical disruption, and implying some sort of regeneration of the apparatus, after the cell has discharged its secretion and returned to rest.

A Golgi net has been demonstrated by numerous observers in the epithelial cells of various glandular organs, and I shall limit myself merely to giving a list of these. The Golgi net was described in the thyroid by Negri (130) and by Kolster (102); in the adrenal medulla by Pensa (135) and Kolmer (100), and in the cortex by Pilat (144), by Mulon (128) and by Kolmer $(100)$; in the anterior lobe of the hypophysis by Gemelli (60), and in both glandular and nervous portions by Tello (172); in the pancreas by Negri (130), by v. Bergen (10) and by Kolster (102), Kolmer (100) and Cajal (31); in the dog's prostate by v. Bergen (10) and in the hypertrophied human prostate by Verson (179) and by Taddei (171). Von Bergen claims to have been able to recognize the net in unstained scrapings of prostatic epithelium kept alive for a time in the prostatic secretion. 
This appears to be the only recorded attempt to observe the Golgi apparatus in the living cell. ${ }^{1}$
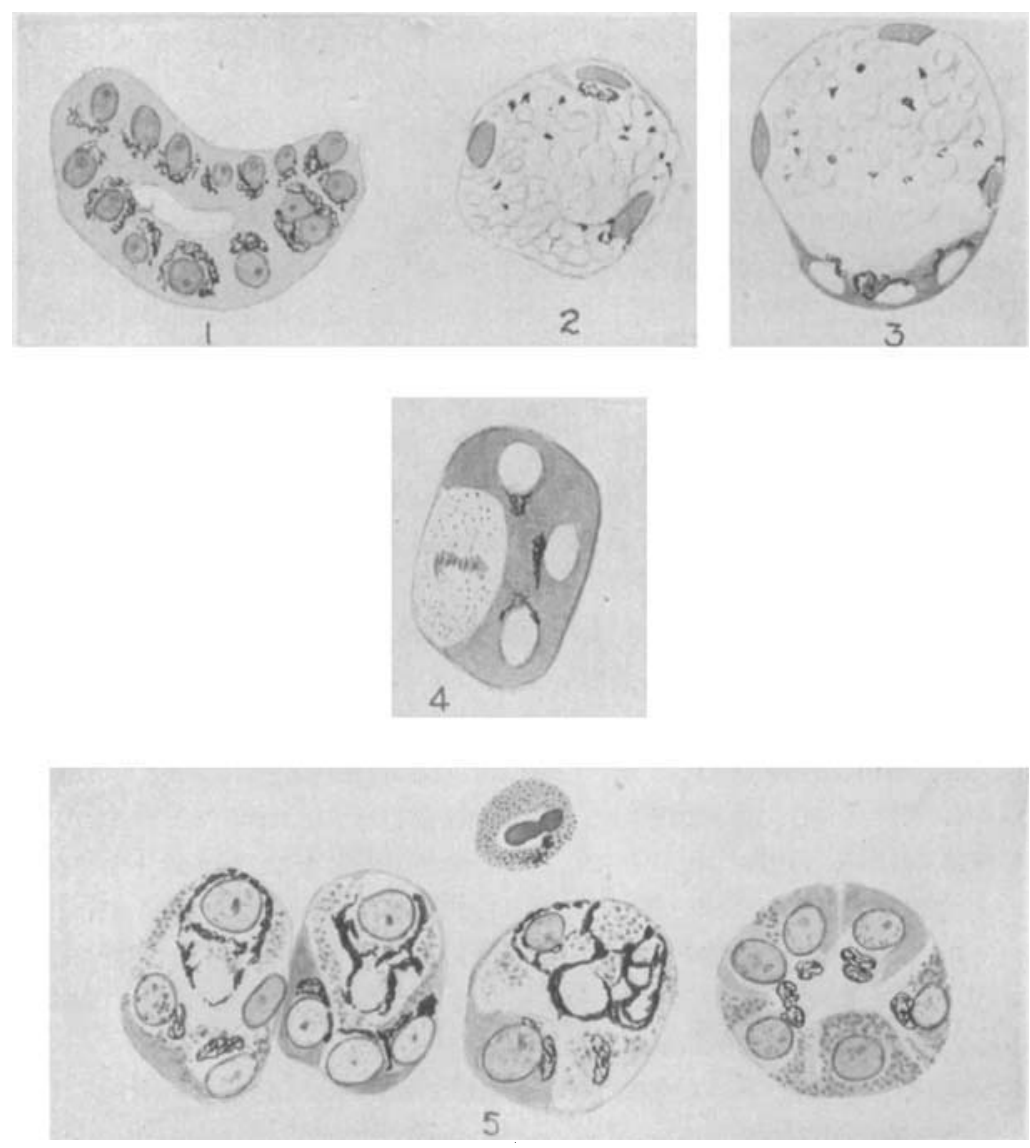

Fig. 1 Tracheal gland, non-secreting. Cajal.

Figs. 2 and 3 Tracheal glands, showing fragmentation of Golgi apparatus during secretion of mucus.

Fig. 4 Small group of thyroid epithelial cells, one in mitosis. Dittokinesis. Cajal.

Fig. 5 Salivary gland of rat. Cajal, anilin-fuchsin-methyl-green. Note relation of Golgi net to Altmann granules.

\footnotetext{
${ }^{1}$ We also have tried to observe it in growing chick embryo cells in vitro, both by direct light and using dark-field illumination, but without success. Lewis and Lewis (109) likewise report their inability to see structures corresponding to the Binnennetz in living chick embryo cells, nor could they be brought out by prolonged osmic acid fixation.
} 
The net has been found further in the epithelial cells of the epididymis by Negri (130), by Fusari ('08), by Kolster (102) and by Kolmer (100); in the ciliated epithelium of the trachea by Kolster (102); in the choroid plexus by Biondi (20) and in the uterine mucosa and chorionic epithelium by Decio (46) and by Acconti (1).

Negri (130), Kopsch (103), v. Bergen (10), Kolster (102) and Kolmer (100) and Cajal (31), record the presence of a net in the salivary gland epithelium. My preparations show one or two points which I do not find mentioned in their descriptions.

I find in some acini remarkably large, coarse-meshed nets, enveloping the nucleus, joining by stout, varicose filaments with nets in adjacent cells, and not infrequently giving origin to trabeculae which loop about the lumen of the gland. They are thus not confined to a single cell, and anastomose freely one with another.

By counterstaining the Golgi preparations by the anilinfuchsin-methyl green modification of Altmann's method, one can clearly recognize the independence of the net from the Altmann granules, which are evenly distributed through the entire cell. Indeed, it seems as if these were an inverse relationthat is, those cells in which the granules are poorly marked and absent, show the most conspicuous and elearly defined net, whereas the large cells which are replete with granules, may contain no net at all. Whether this is a constant relation or not, remains to be seen (fig. 5).

It is surprising that the literature should contain but two references to the presence of a Golgi apparatus in the liver cells. Stropeni (169) is the only one who has succeeded, and he stated that in mammalian livers he obtained only a partial impregnation. With the livers of lower vertebrates, namely frogs and amphibians (Axolotl) he was more fortunate. He found the net to be definitely localized to the portion of cytoplasm between the nucleus and the bile-canaliculi, occasionally sending prolongations into the rest of the cytoplasm; no continuity with the bile canaliculi could ever be observed, nor was there any striking difference in the appearance of the net in fasting or well-fed animals. 
Kolmer (100) says that he succeeded but rarely in demonstrating a net in the liver cells. In a new-born cat, the liver cells contained a simple juxta-nuclear net consisting only of several meshes or sometimes of single polygonal nets with one or two long processes. They had no constant relation to the nucleus.

We also have tried repeatedly to find a Golgi apparatus in the liver cells of rats, and have been almost uniformly unsuccessful with the Golgi or Cajal technique. In only one preparation were there found discontinuous curved filaments distributed through the cytoplasm, and bearing little resemblance to the complex reticulum found in other epithelial cells. By prolonged fixation in 2 per cent osmic acid, one may, however, demonstrate very clear-cut intracellular filaments and rows of granules, often curved and occasionally branching, but never uniting to form a definite network (figs. 6, 7, 8, 9, 10, 11). These filaments may lie against the nuclear membrane; in a few instances they appear to join filaments in neighboring cells; in no case do they connect with the bile canaliculi, nor do they appear to reach the surface of the cell. Whether these structures are the homologues of the Golgi apparatus in other cells, I am unable to say with certainty. Their resistance to impregnation by the usual methods implies some chemical variation. They disappear rapidly during autolysis and are absent in cells injured by chloroform poisoning.

Surprisingly few workers also, have concerned themselves with the Golgi apparatus as it appears in the kidney.

Brugnatelli (25), using the Golgi arsenic method has described a net in the cells of the tubuli contorti and of the tubuli recti of the guinea pig, which coincides perfectly with that of other epithelial cells, especially as regards its localization between the nucleus and the lumen of the tubule. In the collecting tubules the apparatus was much more complicated and definite than in the cells of the convoluted tubules, in which it invariably presented itself as small, very simple, almost simulated (i.e., 'accenata'). It seemed, he says, as if the more complex structures here (basal-rods, granules) were harmful to a clear-cut demonstration of the reticular apparatus. 

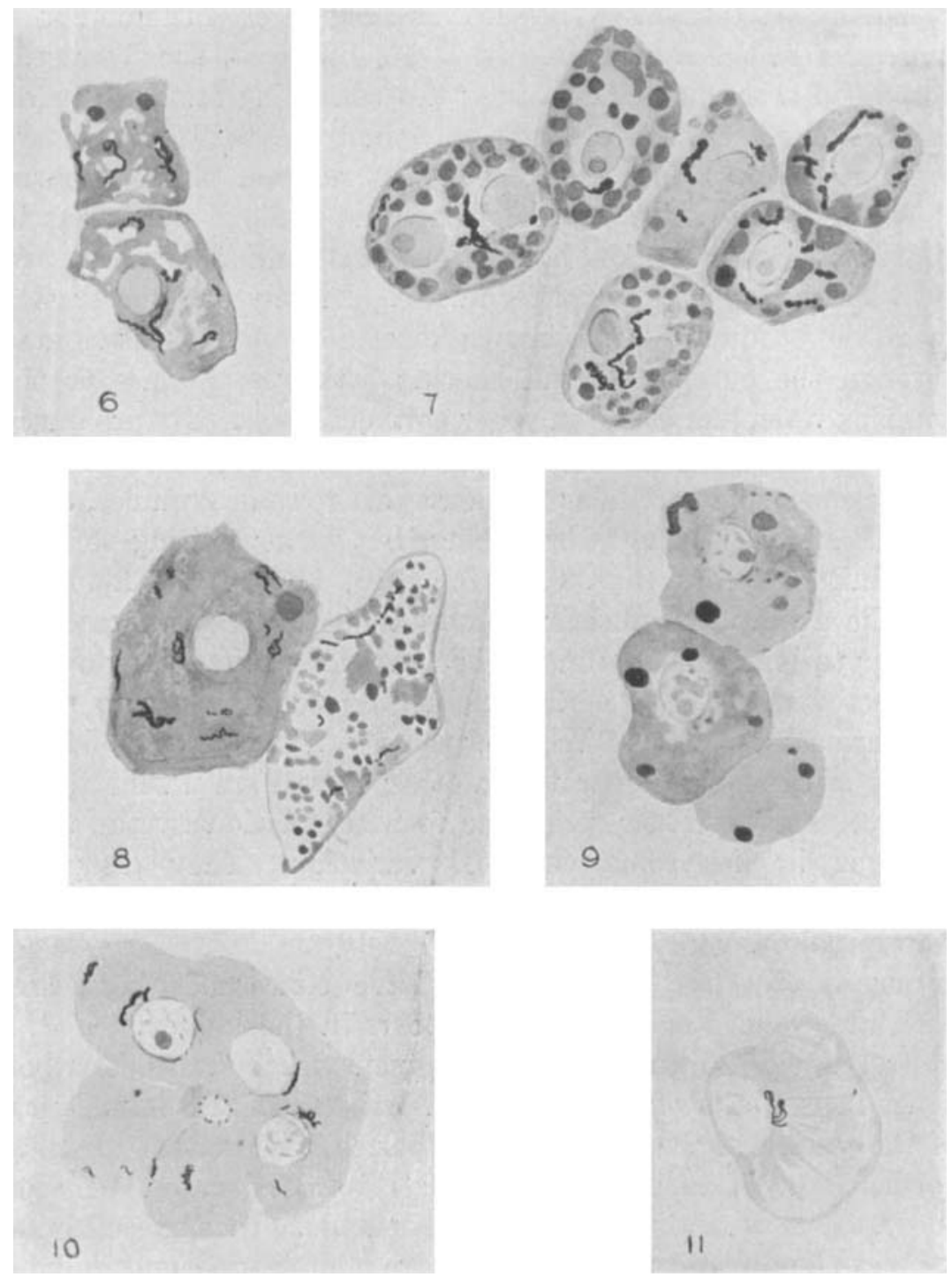

Figs. 6, 7 and 8 Liver cells of rat. Kopseh, 2 per cent osmic acid, 12 days. Fig. 9 Liver cells of rat, autolysed 3 hours at $37^{\circ}$. Kopsch.

Fig. 10 Liver cells, rat. Cajal.

Fig. 11 Liver cell, rat, vacuolated with localized juxta-nuclear Golgi apparatus. Cajal. 
In the glomeruli, the apparatus is reduced to its lowest termssometimes appearing as a simple nodule, or as a small figure 8 , and always lying adjacent to the nucleus. Brugnatelli gained the impression that the net was restricted to the cells of epithelial origin forming the visceral layer of Bowman's capsule. $\mathrm{He}$ is quite wrong in this, as the endothelial cells and the parietal cells of the capsular space also contain an easily demonstrable net (fig. 12).

Barinetti6 ('12) describes and pictures a rather complex net in the renal epithelium, and shows its relation to the centrosomes by comparing it with impregnations in which the centrosome is stained by Benda's method. He omits, however, to mention the portion of the renal tubule to which he refers.

San Giorgi (156) studied the alterations of the Golgi apparatus during experimentally produced nephritis in guinea pigs. $\mathrm{He}$ used as toxic agents, uranium nitrate, cantharidin, ricin and diphtheria toxin.

The modifications observed were a splitting up of the filaments or a granular fragmentation without complete loss of the reticular character. Such modifications were most clearly observed in the tubuli recti of the medulla, in which the net, as Brugnatelli showed, is normally more voluminous and complete than in the cells of the convoluted tubules. Close examination showed relation between alterations of the cells as a whole and of the Golgi apparatus. The fragmentation of the net may be marked in some cells of the tubules, whereas others may contain a normal net.

One may criticize San Giorgi's work because of the fact that none of the poisons used produce obvious changes in the cells of the tubuli recti.

Kolmer (100) briefly records the presence of a net in various elements of the kidney, but gives no detailed description.

We have made numerous preparations of rats' kidneys, both of normal animals and of animals in which a uranium nitrate nephritis had been produced. We have varied the time of fixation from two hours (as recommended by Brugnatelli) to twelve hours, without obtaining striking differences. We have also 


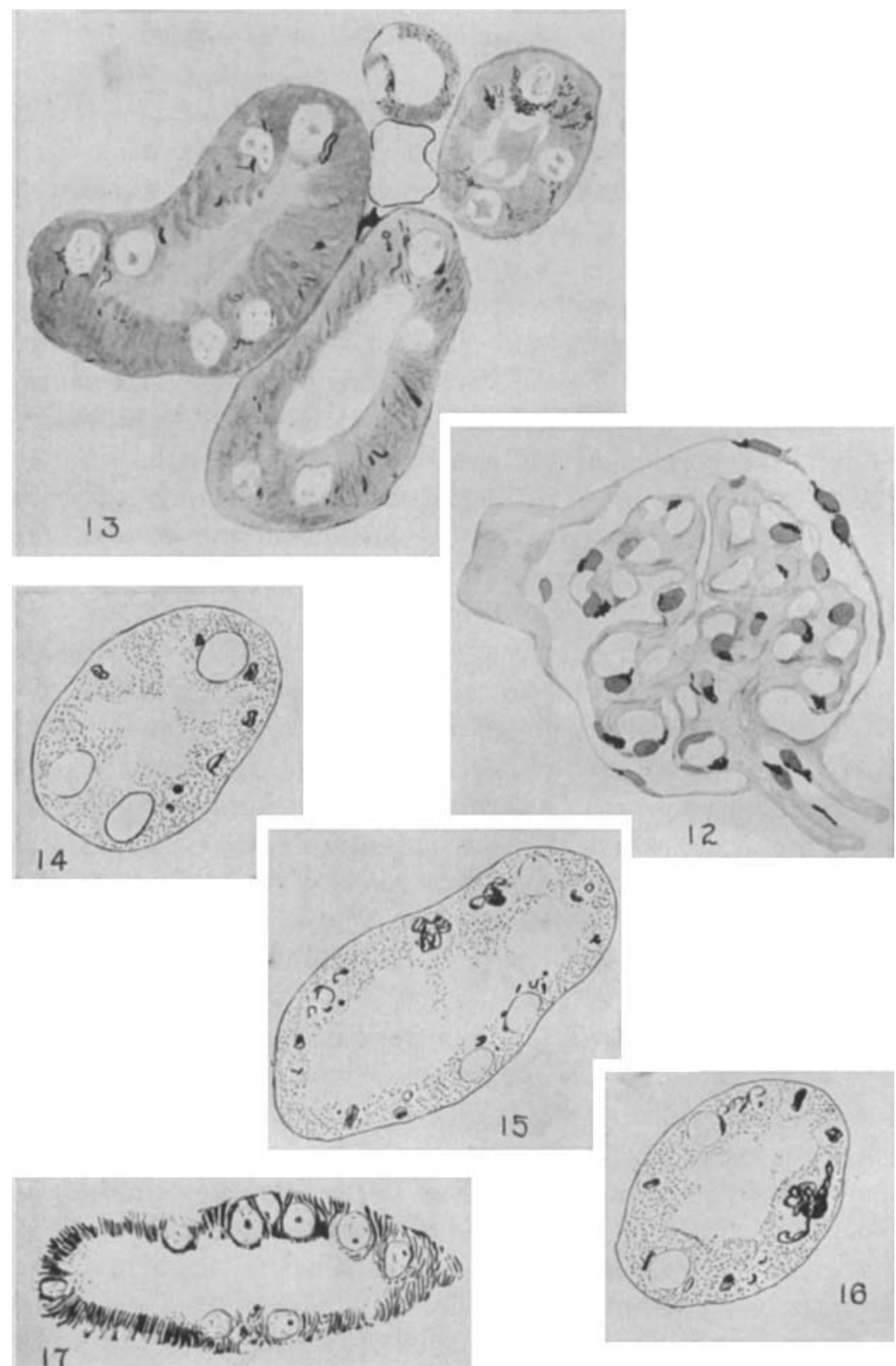


studied, though incompletely, the effect of autolysis, and found that changes were discernable only after an hour at $37^{\circ}$ when the kidney was removed from the body immediately after death. A kidney removed from an animal one hour after death, showed about the same type of structure as the freshly fixed tissue. The apparatus, therefore seems to be somewhat more resistant to autolytic change than the mitochondria, which after half an hour at $37^{\circ}$ were broken up into coarse droplets.

As regards the appearance of the Golgi apparatus in the cells of the convoluted tubules, my preparations do not coincide at all with those of Brugnatelli (25) or San Giorgi (156). The argentophile structures in these cells take on the most bizarre and varying forms. One finds smaller and larger droplets or granules, rings or signet forms often ending in a delicate filament, curved threads, uniform in calibre, or with nodular thickenings and varicosities; and larger, more complicated skeins approaching the reticulum described in other types of epithelial cells (figs. 13, 14, 15, 16). The location of these structures with respect to the nucleus is as variable as their form. Their most frequent site is perhaps at either side of the nucleus, sometimes in contact with it; the filaments in general tend to run at right angles to the basement membrane. Sometimes one finds a cluster of granules and short filaments in the supra-nuclear zone, very rarely between the nucleus and the basement membrane. The appearance varies also from one tubule to another in the same preparation; some tubules may show predominently irregular twisted threads and skeins, others only granulae of uniform or varying size. The appearances are so bewildering in their variety that it is difficult to draw any conclusions, and we are still experimenting with the technique in the hope of getting more constant pictures. We have about decided, however, that the Golgi apparatus in the convoluted tubules is not the

Fig. 12 Rat kidney. Glomerulus. Cajal.

Fig. 13 Rat kidney. Proximal convoluted tubule. Cajal.

Figs. 14, 15 and 16 Rat kidney removed one hour after death. Convoluted tubules. Golgi.

Fig. 17 Rat kidney. Large Henle tubule. Impregnation of basal filaments. Golgi. 
clear-cut definite structure which Brugnatelli depicts, but is normally fragmentary and dispersed. We have not been able to prove that these variations in form are correlated with different phases of secretion.

In the Henle tubules, the net is obscured by a very constant impregnation of the Stäbchen. Sometimes, however, we can distinguish a small, very dense, supra-nuclear network, and occasionally filaments are continued along the lateral aspects of the nuclear membrane (fig. 17).

In the cells of the collecting tubules also, a net has been frequently seen, although in the rat's kidney it is a looser and less complex structure than that described by the Italian workers.

In the glomerular cells, both epithelial and endothelial, the small juxta-nuclear net is constantly found, and very sharply defined and striking (fig. 12).

In the uranium nitrate kidney I have made only a few observations which seem worth mentioning at this time.

In the first place, the more complicated filaments and skeins, usually evident in the normal tubules, tend to disappear entirely in the injured kidney. Even those cells, which in sections counterstained with Giemsa, show little or no obvious damage, rarely show structures other than granules or irregular black or grey-staining clumps. In the totally necrotic and desquamated cells, one often finds a single coarse black clump possibly representing the remains of the argentophile structure.

In many of the injured cells I find oval or circular greyish bodies of varying size, many of which contain one or two eccentrically placed black granules (fig. 19). Now starting with these, one can trace transitions both to small solid black granules and to large droplets which have entirely lost their affinity for the silver-stain, taking the eosin of the Giemsa intensely, and resembling in every way the familiar hyaline droplets of degenerating renal cells. These largest droplets accept the acid fuchsin in the Altmann-Bensley stain, but I have gained the impression that they arise from the argentophile droplets rather than from a breaking-up and fusion of the mitochondrial structures. 

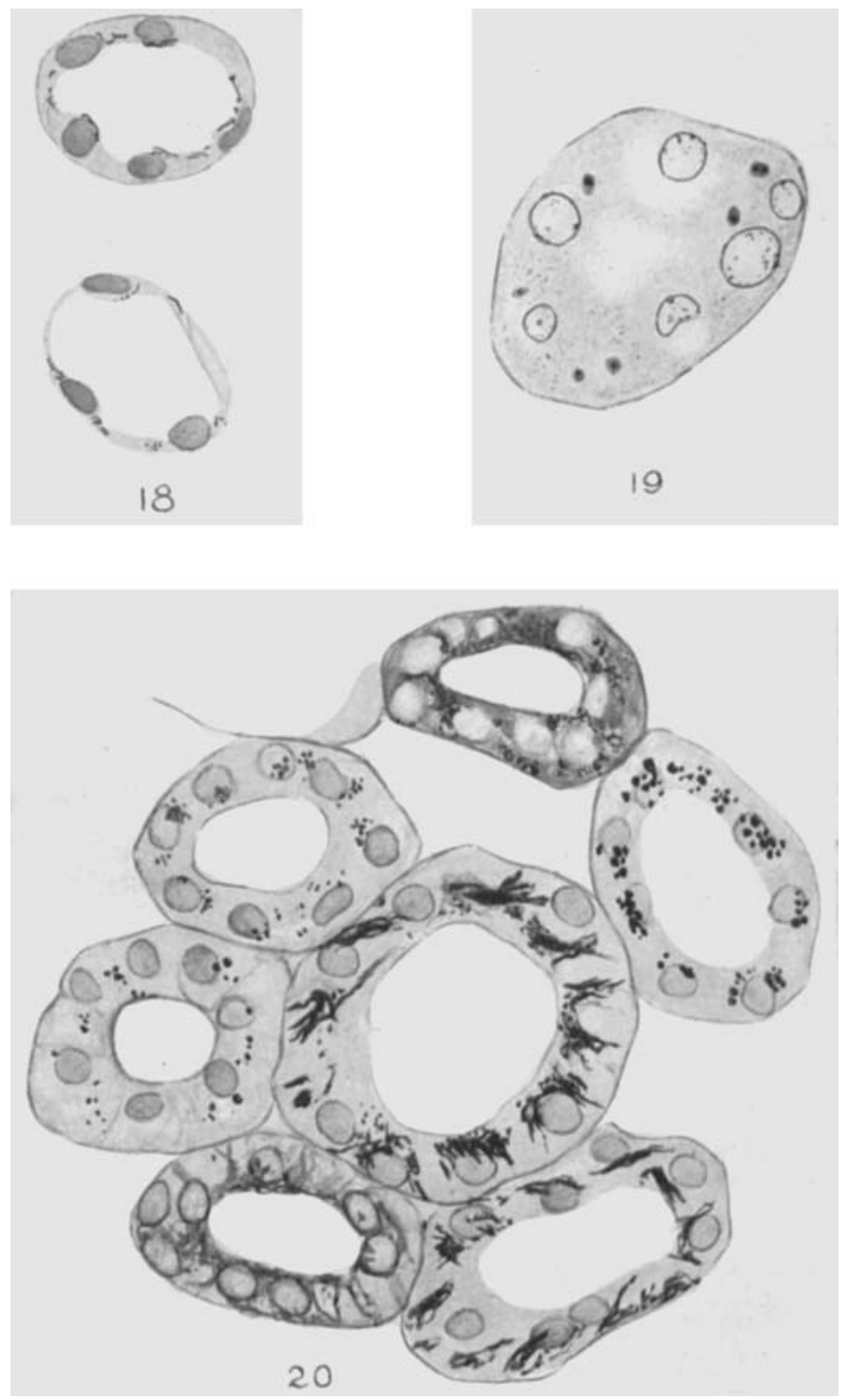

Fig. 18 Rat kidney. Two small collecting tubules with delicate supranuclear filaments. Cajal.

Fig. 19 Rat kidney. Uranium nitrate, Nephritis. Proximal convoluted tubule containing hyalin droplets with argentophile granule. Cajal.

Fig. 20 Frog's kidney. Tubules showing various types of argenthophile structures. Cajal. 
Fahr (52) has also recently made the observation that this type of 'gross-tropfige' degeneration may be produced experimentally in the rabbit's kidney with uranium nitrate, and is disinclined to derive the droplets from the mitochondria of the cell.

The appearances observed in the epithelial cells of the frog's kidney are also very puzzling and difficult to interpret. In the glomeruli, a concentrated juxta-nuclear mass is present in all the cells, identical with that described in the rat's kidney.

In the proximal portion of the convoluted tubule there is found to either side of the nucleus, but rather nearer the distal pole, a small irregular, granular filamentous or ring-shaped mass, which is quite definitely the homologue of the Golgi apparatus of other cells. Such an epithelial cell, cut in a plane parallel to the basement membrane, shows the nucleus surrounded by a ring of discrete masses, which do not form a continuous skein, but are interrupted (fig. 22A).

In frogs injected with trypan-blue this type of apparatus is present in the cells containing the granules of dye, which in general occupy the supra-nuclear zone of the cytoplasm. The dye granules and the argentophile bodies are quite unrelated.

In some of my preparations, the cell boundaries are sharply impregnated by the silver, appearing as delicate black lines. The striated border is also sharply brought out (fig. 22).

In another part of the tubule, probably the distal portion of the convoluted tubule or Schaltstück, which contains no blue staining granules, the argentophile bodies are in the form of rounded globules or granules, varying slightly in size and intensity of staining, and occupying a zone in the middle nuclear plane (fig. 22B). The homology of these granules to the Golgi apparatus is not clear, and it is possible that they represent excretory substances of some sort, possibly chlorides or phosphates (Leschke (109)).

Finally, in still another portion of the tubules (corresponding to the Henle loop) there is obtained an excellent impregnation of the basal filaments and mitochondria (fig. $22 \mathrm{C}$ ). The cytoplasm in the supranuclear zone is somewhat more intensely stained, 
but no definite structures comparable to the Golgi apparatus of other cells is brought out.

This description corresponds to the appearances usually observed in the frog's kidney. Some of our preparations, however, show curious structures of very different type, the nature of which is entirely obscure. These are limited to certain portions of the secretory tubules - probably the distal convoluted portion or Schaltstiuck, although it is not possible to be sure of this.

They consist of sheaves of filaments, often of great length, sometimes beaded or with nodular varicosities. They run either perpendicular to the basement membrane, along the lateral aspects of the nucleus, or in some instances, lie above the nucleus and have a course more or less parallel to the basement membrane (figs. 20-21).

These bundles of fibrils do not appear to form closed skeins or to anastomose with one another, but overlie and cross. The individual fibrils are often irregularly fusiform, with tapering ends. They may be quite rigid, almost crystalline in appearance, or more wavy and filamentous. Scattered amongst them are small isolated clumps and granules of varying size.

b. In ordinary connective tissue cells. A small juxta-nuclear apparatus has been described by v. Bergen (10), Cajal, Deinecke (47) and Kolster (102); in endothelial cells by v. Bergen (10) and by Cajal (28); in smooth muscle cells of blood vessels by $\mathrm{v}$. Bergen (10); and in various types of wandering cells by v. Bergen (10), Verson (179) Maccabruni (115), Barinnetti (6) (Plasmacells-relation to centrosome, '12) and Fananas (55).

In cartilage cells, Pensa (136) first described a distributed apparatus which he considered to resemble the diffuse net found by Golgi in the ganglion cell. Later v. Bergen showed that the Golgi apparatus in cartilage cells, as in most other non-nervous elements, was limited to the juxta-nuclear region, and interpreted Pensa's diffuse apparatus as a chondriom. Pensa (137) has accepted this correction, and v. Smirnow (165), Barinetti (6) and Kolster (102) are in agreement with v. Bergen on this 


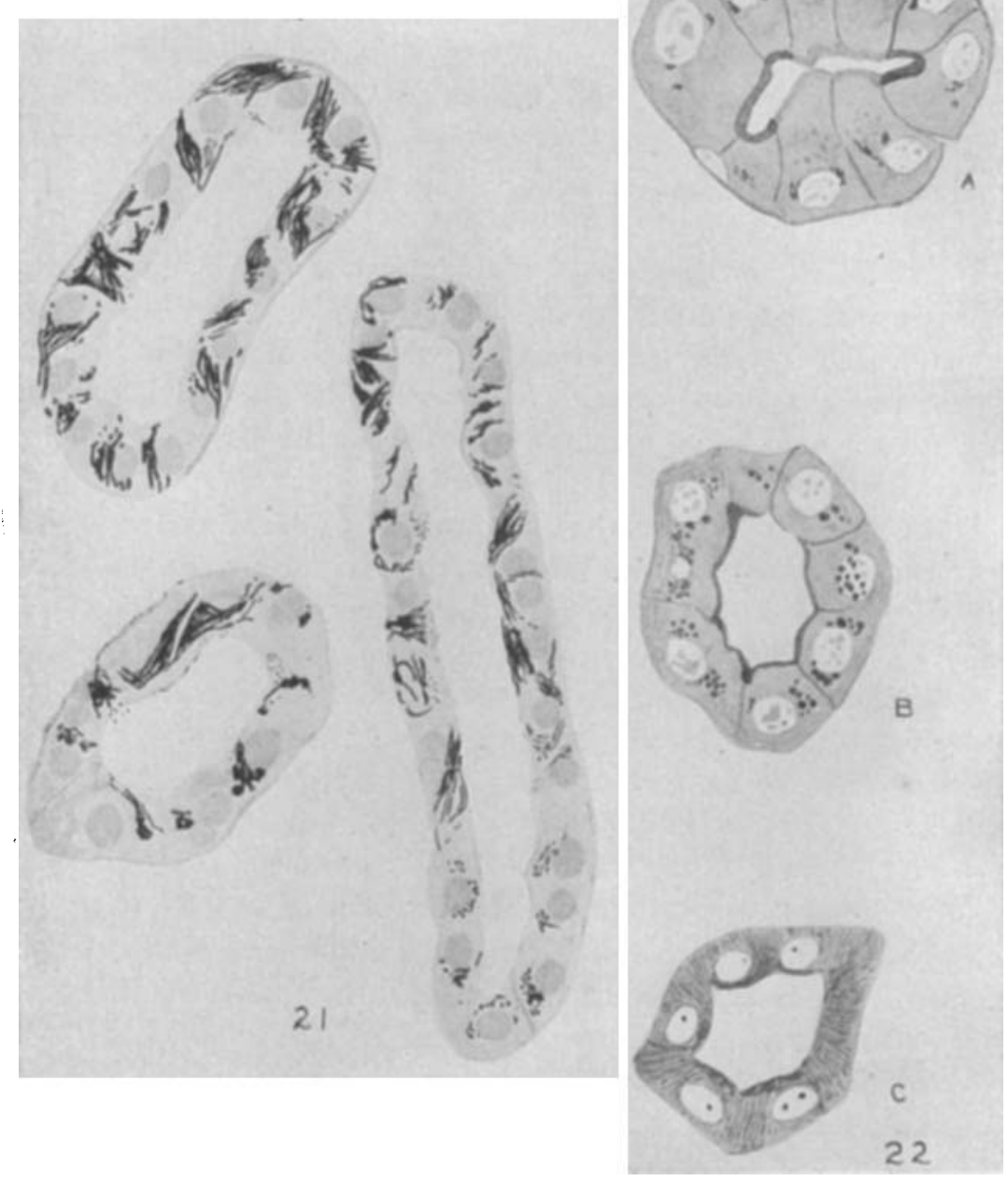

Fig. 21 Frog's kidney. Tubules showing argentophile filaments. Golgi.

Fig. 22 Frog's kidney. A-Proximal convoluted tubule. Golgi apparatus in the form of discrete peri-nuclear filaments, rings and loops. B-Tubule containing argentophile droplets. $\mathrm{C}$-tubule showing impregnation of basalrods. 
point. Comes $(40,41)$ still claims that Golgi net and mitochondria in cartilage cells are identical structures.

The controversy is interesting, because it has brought out the point that the silver method is not always specific, and that under certain conditions the mitochondria may be impregnated. This occurs regularly, as I have mentioned, in the Henle tubules of the kidney.

Both Pensa (136) and Cajal (31) have described an interesting series of changes in the zone of growing cartilage adjoining the line of ossification. Following the enlargement of the cells the net loses its localized character, hypertrophies and finally, with the degeneration of the cartilage cell, undergoes granular disintegration.

Cajal (31) seems to have been the only one to study the behavior of the Golgi apparatus in osteoblasts. During the period of functional activity, the net is very well developed, and large, usually occupying that part of the cell directed towards the osteoid tissue. In the finished bone corpuscle, the net shrinks to a small compact mass.

Teeth. Although Massenti (123), using pig embryos, had previously described a Golgi apparatus in the form of a large skein occupying almost the entire cytoplasm of the pulp cells and odontoblasts Cajal (31) depiets structures of a more typical character and localization. As the odontoblast becomes differentiated from the connective tissue elements of the pulp, the net increases in size, and comes to form a large oval rather granular mass, occupying the supra-nuclear portion of the cytoplasm. The further fate of the structure could not be followed, since decalcification interferes with the reaction, but Cajal regards the hypertrophy during the secretory phase of the odontoblast as another example of the cyclical changes seen in goblet cells, growing cartilage cells, etc.

Muscle fibers. There are a number of papers dealing with the endo-cellular reticulum of striated muscle fibers. The earliest is that of Cajal (26), in which he found in the wing muscle of certain insects a network continuous with the ramifications of the tracheal tubes, and therefore probably a true cana- 
licular system. This was confirmed by Fusari in 1894 for mammalian muscle and by Veratti (178) in 1902. Veratti, however, denied that the endocellular apparatus in insects represented a continuation of the tracheal tubes, and regarded it as composed of solid filaments. Sanchez (155), a pupil of Cajal, confirmed the tracheal origin of the reticulum in insects, looking upon it as a tubular apparatus, probably of importance for the nutrition of the fibers. The system is composed of transverse meshes on either side of the 'bandes claires,' united by longitudinal connections.

Two other recent papers, one by Martinotti (122), the other by Fananas (54) have not been available.

Quite different is the apparatus described by Luna (113) in the cardiac muscle fibers. Here he finds granules, rods, curved filaments or more complete nets lying at one or both poles of the nucleus. He believes that the granules and rods might possibly be mitochondrial.

c. Gonads. The studies upon the gonads are of much more theoretical interest, because of their bearing upon the question as to whether the Golgi apparatus is a permanent structure, and a heritable constituent of the cytoplasm, or whether it is more ephemeral in character, and related to the vegetative activities of the cell. It is also in the sperm cells that the topographical relation of the net to the centrosphere is most evident, so that the structure during spermatogensis might be expected to show interesting modifications.

Platner (145), a number of years before the discovery of the Golgi apparatus, had described a structure surrounding the centrosomes of the spermatogonia, which he called a Nebenkern. Heidenhain (68) in 1900, in the sperm cells of Proteus, found with the iron hematoxylin stain, an incomplete basket-work surrounding the centriole. Heidenhain used the term Zentralkapsel or pseudo-chromosomes for these bodies, and believed that they were formed by special differentiation from the Benda mitochondria. This view finds support in the recent observations of Chambers (33) upon spermatogenesis in the grasshopper, in 
which the mitochondria, vitally stained with Janus green, appeared to enter directly into the formation of the Nebenkern.

Sjövall (164), using a modification of the Kopsch method, demonstrated these structures in the spermatocytes, spermatogonia and spermatids of the white mouse, and concluded that Heidenhain's view of their mitochondrial origin was erroneous. Benda, and especially Weigl (180), have also taken this stand. Sjövall also found a net in the Sertoli cells.

Perroncito (140, 141), using the Golgi method, carried the observations of Sjövall a step further, by describing the alterations of the net during the maturation divisions. He finds in Paludina, that in the prophase, the net breaks up into granular fragments, which he calls dittosomes, and which are distributed equally to the two daughter cells. The skeins are then reformed from the granules, and in the spermatids come to occupy their usual juxta-nuclear position. This process of fragmentation and distribution during mitosis he calls dittokinesis.

The fate of the Golgi apparatus in the adult spermatozoa is unknown, nor has it been established that the substance of which it is composed enters the egg during fertilization. The phenomenon of dittokinesis, however, is established, not only for the sperm cells, but also for the somatic cells (fig. 4). Deinecke (47) ('12) has given a very clear description of this process in the flat cells of Descemet's membrane, where the net forms in the resting cell a thick skein of interwoven and anastomosing threads. During karyokinesis the skein becomes looser and gradually surrounds the nucleus, the individual threads grow thicker, loose their connection and break up into unequal bent fragments which are heaped up at the poles of the nucleus. During anaphase they change into short thick rods and granules surrounding the nuclei, and lying chiefly in the equatorial plane. The size of these dittosomes is only slightly smaller than that of the chromosomes, their number somewhat greater. With the formation of the diaster, the dittosomes surround the daughter chromosomes, being more densely aggregated at both poles. The region of the spindle remains free of them. 
The new nets are formed by a fusion or sticking together of the granules or rods, but may remain discreet for a time. In this way, it is possible to recognize a recent mitosis, even after the nuclei have reformed.

During the monaster stage one sees often a pairing of the granules and double rods. Whether this indicates a splitting of the dittosomes comparable to that of the chromosomes, Deineke leaves undecided. At any rate, the above series of changes unquestionably leads to an even distribution of the mass to the two daughter cells.

Studies of the Golgi apparatus in the female gonads have been made by Sjövall (164), Weigl (180), Cattaneo (32), and Kulesch (104), and Weigl (180) and Hirschler (70) in the ovocytes of invertebrates; in the primitive germ-cells of 3-4 day chick embryos by v. Behrenberg-Gossler (16). All these writers are in substantial agreement as to the main facts namely, that in the young ovocytes and in the follicle cells, there is a circumscribed net at one pole of the nucleus, which in the ripe ovum breaks up into filaments and granules (or, according to Kulesch, small irregularly angular rings, bent threads and dises) which are with difficulty distinguished from the mitochondria and other cytoplasmic granulations.

\section{THE GOLGI APPARATUS IN EMBRYONAL CELLS}

The recognition by Golgi (64), Fananas (54) and Cajal (31) that the Golgi apparatus is present in all types of cells, even at a very early stage of development (chick embryos of 30-40 hours-Cajal) seems to establish firmly the principle that the structure is an important and constant component of the cell.

In many of these fetal cells-the mesenchyme- the endothelium of the pericardium and of the primitive blood spaces-the cells of the Wollfian ducts and the entoderm of the intestinal tract, the neuroblasts, and even the erythroblasts and wandering cells, the apparatus is highly typical and constant in its relation to the centrosphere.

The attempt has been made by Fananas to trace the development of the net from granules and batonnets in the cytoplasm. 
As Cajal (31) points out, however, the not infrequent impregnation of the mitochondria and of skeletal and sustentacular structures in early embryonic cells makes such an interpretation doubtful.

One general principle can be deduced from a study of the Golgi apparatus in embryonic tissue, and that is the definite polarity of the structure in all fixed non-mobile cells. The location of the net in every case, as Cajal has pointed out, is such that it occupies the 'external' part of the cell,--that is, the portion above the nucleus directed originally towards the free surface, and opposite that pole which is towards the interstitial tissue and the nutrient supply. This polarity is preserved in adult life in the case of epithelial cells lining ducts and cavities, but may be lost in the case of solid glandular organ or tissues which undergo profound modification and derangement during development. The significance of this polarity which would seem to be bound up with the relation of the Golgi net to the centrosphere, is by no means clear, but it seems to be one of the most fundamental and most striking characteristics.

VI. THE GOLGI APPARATUS IN PROTOZOA

The literature contains but one reference to the oceurrence of the Golgi apparatus in Protozoa. Hirschler (70) describes in the cytoplasm of Monocystis ascidiae, a Gregarine parasite of the ascidian Ciona intestinalis, diffusely scattered ring and half ring forms, demonstrable by prolonged exposure to 2 per cent osmic acid and resistant to turpentine (Sjövall's modification of the Kopsch method). Whether these structures are the homologues of the Golgi apparatus of the metazoan cell, needs further study.

\section{THE GOLGI APPARATUS UNDER PATHOLOGICAL CONDITIONS}

The modifications which the Golgi apparatus undergo under pathological conditions have been little studied, and, so far, have not added any new suggestions as to the real nature of the structure. 
In the cells of malignant growths, Golgi nets, often atypical, have been found by Moriani (125) in a human breast carcinoma, by Veratti (177) in a transplantable mouse cancer; by Lucioni (112) in a naevus; by Savagnone (157) in carcinoma of the breast, in a sarcoma of the jaw and in a giant-celled sarcoma; by Tello (172) in carcinoma and adenoma, in epithelioma and in experimental granuloma caused by Kieselguhr injections. Tello studied especially the distribution of the net in foreign body giant cells, where there are multiple nets-one usually in relation to each nucleus. In tuberculous giant cells, on the other hand, as shown by Fananas (55), the net is usually centrally placed, in relation to the multiple centrosomes.

Regressive changes (fragmentation, pulverization, etc.) in the Golgi net have been described by Fananas (55) in caseating giant cells; by Marcora (117) in the ganglion cells of the hypoglossal nucleus, following avulsion or section of the nerve; by Battistessa (8) in the ganglion cells of animals poisoned by lead or strychnin; by San Giorgi (156) in toxic nephritis, and by Del Rio Hortega (97) in the ganglion cells of a case of paralytic rabies.

Very interesting are the recent experimental studies of Cajal (31) dealing with the effect of traumatic injury of the nerves upon the Golgi apparatus.

An incision of the central nervous tissue brings about complete destruction of the net only in those ganglion cells most severely injured by the trauma. The apparatus of cells near the line of incision, though perhaps slightly compressed or deformed, shows no grave disorganization. This would indicate a considerable fixity of structure, and firmmess of texture, since, were the impregnated substance of fluid consistence, one would expect to find it dispersed through the cytoplasm or confluescing into larger droplets.

Cajal has further established the fact that section of a peripheral motor nerve had no effect upon the structure of the Golgi apparatus in the central ganglion cell. There does occur a degeneration of the apparatus in the cell of the sheath of Schwann, distal to the section. 
There are thus very few controlled studies of the alterations of the net under experimental conditions, and it seems tha ${ }^{+}$ something further should be added to our knowledge in that way. The great difficulty had been, and will be, the capricious behavior of impregnation methods; until simpler and more reliable methods shall have been discovered, the interpretation of slight variation in the morphology of the structures will always be open to considerable suspicion.

\section{GENERAL CONSIDERATIONS}

This completes the list of cells and tissues in which structures of this type have been demonstrated. They may be considered as universally present in every type of cell, although the variety of form which they assume at once brings up the query as to whether they are all homologous structures. That, I think, is almost impossible to answer until we know something of their function and significance. Morphologically there seems to be no single character by which we can group them altogether. The staining reactions are probably not entirely specific; we have found instances - as for example in the Henle tubules and in cartilage cells-in which mitochondrial structures are more or less regularly impregnated by the silver methods.

In many types of cells in which the location of the centrosome is known, there is, as Barinetti (6) insists, a topographical relation between Golgi net and cytocentrum. But such a relation cannot be established for the ganglion cells, in which the net completely encircles the nucleus, nor for the muscle cell, nor for the cells of the choroid plexus, still less for the cells of the convoluted tubules, or for the liver cells. So that this criterion is not universally applicable, at least to fully differentiated and highly specialized types of cells.

Much of the discussion about the nature and homologies of these things has hinged about the question as to whether they are solid, that is fibrillary; or canals filled with fluid, and made to appear as solid filaments by the metallic impregnation methods. With the canalicular theory the name of Holmgren is associated, and though there are many shades of opinion in 
regard to detail the general idea that these nets and filaments represent canals with or without definite walls, has had the support of such expert histologists as Studnicka (170), Retzius (149), Cajal (31), and, in this country, of Bensley (14) and Cowdry (42). Holmgren was not the first to observe 'endocellular canals' or 'Saftkanälchen.' As far back as 1887 Nansen (129) described in the protoplasm of nerve cells of Homarus and in the spinal ganglion cells of Myxina glutinosa, primitive tubes consisting of hyalin contents enveloped in sheathes of spongioplasm. These were probably identical with the Saftkanälchen. Nelis (132) also described an 'état spirémateux' in the cytoplasm of certain mammalian nerve cells. He speaks of 'bandes incolores' of about the same diameter, sometimes straight, sometimes convoluted which did not branch, and therefore formed no reticulum. This spireme was not constantly found, and does not seem to be the same thing as the Golgi net.

Holmgren (73) made his first contribution to this subject in 1899, a year after Golgi's first paper, and without, apparently, knowing of the work of Nansen and Nelis. In the spinal ganglion cells of rabbits and of Lophius piscatorius he found an endocellular system of canals communicating with the pericellular lymph spaces; and in the following year he published a large monograph on the ganglion cells of Lophius (72). His earlier views, expressed in these papers, that the endocellular Saftkanälchen are to be regarded as lymph channels, and are thus continuous with structures of connective tissue origin, were later abandoned by him.

Morphologically Holmgren considered his canaliculi to be identical with the Golgi net, basing his opinion upon a study of his own preparations, and those of Retzius, prepared according to the earlier Golgi technique.

In 1900 (76), in a study of the ganglion cells of Helix pomatia Holmgren described a penetration of the nerve cells by cellprocesses from surrounding cells. This view was developed in subsequent studies. The penetrating cells of neuroglial origin he called trophocytes, and to the network formed by the penetrating cell processes, he applied the term trophospongium. 
These prolongations of the trophocytes, he believed, became canalized by a vacuolization of their cytoplasm, the confluescence of the vacuoles giving origin to the canal. This was an irreversible. process, but the cell prolongation was capable of amoeboid motion within the host cell.

Studies on various tissue cells, which I shall not review in detail, confirmed him in his view, and lead him to the following generalization. The cells of the body are of two orders of physiological dignity-high and low. Those of exalted function are the nerve cells, muscle cells, sex cells, certain glandular cells. The lower order of cells, which are the trophocytes, function as servitors, looking after the wants of their more specialized neighbours by means of their trophospongia.

Although this hypothesis is vaguely expressed, and open to obvious criticism, Holmgren has maintained it in a long series of papers (77-96), many of them controversial, and adding no new evidence. The arguments against any such generalized conception are apparent enough. To what order shall we assign the leucocytes and other wandering cells? Where are the trophocytes of cartilage cells? Why have the trophocytes about the ganglion cells, as well as all the other types of cells classed with the lower order, endocellular nets, and what cells look after their lowly wants?

Holmgren has always insisted vigorously upon the identity of his trophospongium with the Golgi apparatus; on the other hand, all who have worked with the Golgi or Cajal methods deny that the structures which they bring out reach the surface of the cells or communicate with other cells. Even Cajal, who regards the Golgi structures as canaliculi, believes them to be wholly endocellular, except perhaps in the special case of the insect muscles, in which the homology with the Golgi net is not very clear at best.

Ross (153) in a recent paper on the trophospongium of the ganglion cells of the crayfish, describes the penetration of the cytoplasm by partitions and fibrils from the surrounding neuroglia, but rejects the idea that these have any relation to the internal reticular apparatus. 
This view, I think, may be accepted without reserve; nor does it seem that Holmgren's generalizations are based on sound evidence, nor that they have added much of value to the subject.

Leaving aside, then, this controversial phase of the subject, one may ask what can be said as to the more intimate physical structure of the Golgi apparatus. It seems to the writer, that the conceptions of Cajal (31) best meet the observed and established facts. Cajal's view is that the apparatus represents a canalicular system, filled with a lipoid-containing substance which reacts to the specific impregnation methods employed. The walls of this system are presumably fairly fixed and rigid in cells of a sedentery habitus, and permanent form, but more plastic in secretory cells and in young cells frequently undergoing mitosis.

It seems probable that the quantitative changes observed during activity indicate a using up of a store of stainable material within these canaliculi, and that the re-appearance of the net during the quiescent stage is due to the re-accumulation of the substance within more or less preformed and permanent channels. What purpose this material serves in the cell metabolism, and what is its more intimate chemical structure, are questions unanswerable with the data at hand.

\section{SUMMARY AND CONCLUSIONS}

There is present in the somatic and sex cells of all metazoa, and possibly also, of protozoa, a cytoplasmic structure of considerable complexity and size. demonstrable by prolonged fixation in osmic acid, or by silver impregnation and reduction. The reaction of this structure to osmic acid indicates, of course, a lipoid component, but there are no other data bearing upon its chemical composition. Nor is anything certain known of its physical characters. Its invisibility in the living cell would indicate a low refractive index. The fundamental question as to whether the impregnated structures are canalicular or filamentous remains unsolved. The constant topography in many types of cells, particularly the definite relation to the cytocentrum would favor the idea that the structures are at least in part 
solid, rather than casual rifts or fluid-filled canals in the cytoplasm. The fragmentation or dispersion of the net which occurs during certain secretory phases, or accompanying pathological changes in the cell, and particularly during cell division, would also suggest a solid or semi-solid consistence.

The Golgi apparatus in the secretory portion of the renal tubules does not conform to the usual closed skein found in many types of glandular epithelial cells, but is dispersed and assumes complex and varying forms. In the glomerular cells, on the other hand, and in the epithelium of the collecting tubule and of the pelvis the structure is more typical both in form and location.

Injury to the epithelial cells of the convoluted tubules (uranium nitrate poisoning) is followed by complete disintegration and disappearance of the Golgi apparatus. This appears to precede the complete necrosis of the cell. The large hyalin droplets found during the degeneration of the cells contain an argentophile component possibly derived from the remains of the Golgi apparatus.

The structures brought out by the Golgi or Cajal technique are more resistant to autolysis than are the mitochondria.

There occurs regularly in the rat's kidney an elective impregnation of the mitochondrial filaments of certain portions of the Henle loops. This illustrates the fact that the method is not absolutely specific.

The writer wishes to express his thanks to the Marine Biological Laboratory of Woods Hole for according him the privileges of the Laboratory during the summer of 1915-1916; and to Dr. E. V. Cowdrey for helpful suggestions and criticism. 


\section{BIBLIOGRAPHY}

(1) Accontr, 1912 Di alcuni fini particolarità di struttura della mucosa uterina della decidue e dell' uovo. Boll. Soc. Med. Chir. di Pavia, $25,125$.

(2) ArNold, J. 1908 Haben die Labzellen Membranen u. Binnennetz. Anat. Anz., 32, 257.

(3) Ancona, 1909 Apparato reticolare nelle cellule della ghiandola Iachrymale. Diss. di laurea (unedita) Pavia.

(4) Ballowitz, 1900 Ueber d. Epithel. d. membrana elastica posterioris des Auges, seine Kerne u. eine merkwerdige Struktur seine grosse Zell-sphaeren, U.s.w. Arch. Mikr. Anat., 56, 230.

(5) 1900 Eine Bemerkung zu den v. Golgi und seine Schülern beschriebenen 'apparato reticolare intorno' der Ganglien u. Drüsenzellen. Anat. Anz., 18, 177.

(6) Barinetri, 1912 L'apparato reticolare intorno e. la centrospera nelle cellule di alcuni tessuti. Boll. Soc. Med. Chir. di Pavia, 25, 289.

(7) 1911 Di una fina particolarita di struttura nelle cellule del epitelio della cornea. Boll. Soc. Med. Chir. di Pavia, 5.

(8) Batistessa, 1911 Sulle alterazioni dell apparato reticolare interno delle cellule nervose dei gangli spinali in seguito ad advelenamento da piombo e stricnino. Riv, ital. di Neuropatologia, 4, 345.

(9) Benda, 1902 Weitere Mittheilungen über die Mitochondrien. Ergebn. d. Anat. u. Entw., 12, 743.

(10) v. BerGeN, 1904 Zur Kentniss gewisser Strukturbilder (Netzapparate Saftkänalchen, Trophospongien) im Protoplasm verschiedener Zellarten. Arch. f. Mikr. Anat., 64, 498.

(11) Besta 1910 Sull' apparato reticolare intorno (apparate di Golgi) della cellula nervosa. Anat. Anz., 36, 476.

(12) 1911 Ricerche sull reticolo endocellulare degli elementi nervosie nuovi metodi di dimonstrazione. Riv. di patol. nerv. e. ment., 16, 341.

(13) Bialkowska and KulikowsKa, 1911 Uebèr d. Golgi-Kopsch'en Apparat der Nervenzellen bei den Hirudineen u. Lumbricus. Anat. Anz., 38, 193.

(14) Bensley, R. R. 1910 On the nature of the canalicular apparatus of animal cells. Biol. Bull. Mar. Biol. Lab. of Woods Hole, 19, 179.

(15) 1911 Studies on the pancreas of the guinea pig. Am. Jour. Anat., $12,297$.

(16) Berenberg-Gossler, 1912 Ueber gitterkapselartige Bildungen in den Uhrgeschlechtszellen v. Vogelembryonen. Vorl. Mitth. Anat. Anz., 40,587 .

(17) 1912 Verh. d. Anat. Ges. Muenchen., 26, 263.

(18) 1912 Die Uhrgeschlechtszellen der Hühnerembryonen am 3ten u. 4ten Bebrütungstage, mit. besonder Berücksichtigung der Kernplasma Strukturen. Arch. f. Mikr. Anat., 81, Abteilung, ii, p. 24.

(19) Bialkowska u. Kulikowska, 1911 Ueber den feineren Bau der Nervenzellen bei verschiedenen Insekten. Bull. Acad. Se. Cracovie. CI. Se. math. ef nat. 
(20) BIondi, 1911 Sulla fina struttura dell' epitelie dei plessi coroidei. Arch. f. Zellforsch., 6, 387.

(21) Bizzozero E Bottesella, 1909 Sull' apparato interno nelle cellule delle ghiandole sudoripare e sebacee. Arch. per le Sc. med., 33, 279.

(22) B-örкenHeIM, 1913 Golgi's apparato reticolare intorno in den Placentar-epithelien. Arch. f. Gynek., 100, 446.

(23) Bouin et ANCEL, 1905 Apropos du 'trophospongium' et des 'canalicules du suc.' Comptes Rend. de la Soc. de Biol., 2, 221.

(24) Browicz, 1902 Meine Ansicht über den Bau der Leberzelle. Virch. Arch., 168, 1.

(25) Brugnatelli, 1908 Di una fina particolarità di strutturi degli epitelii dei tubuli renali. Boll. Soc. Med. Chir. di Pavia, 22, 96.

(26) Cajal, Ramon y, 1890 Coloration par la méthode de Golgi des terminaisons des trachées et des nerfs dans les muscles des ailes des insectes. Zeitschr. f. Wiss. Mikr., 7, 332.

(27) 1904 El apparato tubuliforme del epitelio intestinal de los mamiferos. Trab. del Lab. Invest. Biol. Madrid, 3, 35.

(28) 1908 Les conduits de Golgi-Holmgren du protoplasm nerveux at le reseau pericellulaire de la membrane. Trab. del Lab. Invest. Biol. Madrid, 6, 123 .

(29) 1912 El apparato endocellular de Golgi de la celula de Schwann y algunas observaciones sobre la estructura de los tubos nervosa. Trab. del Lab. Invest. Biol. Madrid, 10.

(30) 1912 Fórmula de fijación para la demonstración fácil del apparato reticolar de Golgi y. apuntes dobre la disposición de diche apparato en la retina, en las nervios y algunos estados patológicos. Trab. del Lab. Invest. Biol. Madrid, 12, 209.

(31) 1914 Algunas variaciones fisiológicas y patológicas del aparato reticular de Golgi. Trab. del Lab. de Invest. Biol., 12, 127.

(32) Catraneo, 1914 Ricerche sulla struttura dell' ovario dei mammiferi. Arch. ital. de anat. e di embriol., 12, 1.

(33) Chambers, 1915 Microdissection studies on the germ cells. Science, NS., 41, 290.

(34) Craccio, 1903 Communicazione sopra i canaliculi di secrezions nella capsula soprarenali. Anat. Anz., 22, 493.

(35) Сонn, 1903 Zur Histologie u. Histogenese des Corpus luteum u. des interstitiellen Ovarialgewebes. Arch. f. Mikr. Anat., 62, 745.

(36) Colson, 1910 Histogenese et structure de la capsule surrénale adulte. Arch. de biol., 25, 535.

(37) Collin et Lucien, 1909 Observations sur le réseau interne de Golgi dans les cellules nerveuses de mamiferes. Comptes rend. de la Soc. Anat., Nancy.

(38) 1914 Algunas variaciones fisiológicas y patológicas del aparato reticular de Golgi. Trab. Lab. de Invest. Biol., 12, 127.

(39) 1909 Sur les rapportes du réseau interne de Golgi et des corps de Nissl dans Ia cellule nerveuse. Bibl. Anat., 19, 123.

(40) Comes, 1909 Sulla natura mitocondriale dell' apparato reticolare delle cellule cartilagine. Boll. Acad. giolinica di sc. nat. Siena, Ser. II, fasc. 6. 
(41) 1913 Apparato reticolare o condrioma? Condrocinesi o dittocinesi? Anat. Ant., 43, 422.

(42) CowDREr, 1912 The relations of mitochondria and other cytoplasmic constituents in spinal ganglion cells of the pigeon. Int. Monatsch. f. Anat. u. Phys., 29, 1.

(43) D'Agata, 1910 Sulle modificacazioni dell' apparato reticolare interno nell' epitelia della mucosa gastrica. Boll. Soc. Med. Chir. di Pavia, 25,517 .

(44) 1910 Di una fina particolarità di struttura delle cellule epiteliali della cistifellea. Boll. Soc. Med. Chir. di Pavia, 25, 531.

(45) 1911 Ueber eine feine Struktureigenthümlichkeit der Epithelzellen der Gallenblase. Arch. f. Mikr. Anat., 77, 78.

(46) Decro, 1910 Sulla minuta struttura dell' epitelio uterino. Boll. Soc. Med. Chir. di Pavia, 25, 476.

(47) Detneke, 1912 Das Netzapparat von Golgi in einigen Epithel-u. Bindegewebszellen während der Ruhe und Teilung derselben. Anat. Anz., 41, 289.

(48) Duesberg, 1914 Trophospongien und Golgi'schen Binnenapparat. Verh. d. Anat. Ges., 46, 11.

(49) 1912 Plastosomen, 'Apparato reticolare interno,' und Chromidalapparat. Erg. d. Anat. u. Entw., 20, 567.

(50) EllermanN, 1899 Ueber die Struktur der Darmepithelzellen von Helix. Anat. Anz., 16, 590.

(51) Erhard, 1910 Studien über Trophospongien. Zugleich ein Beitrag. z. Kenntniss der Sekretion. Festschr. f. R. Hertwig, 50, 133.

(52) FAHR, 1914 Zur Frage der Hyalintropfige Zelldegeneration. Verh. d. deutschen Path. Ges., 17, 110.

(53) Fananas, 1912 El apparato endocellular de Golgi de la mucosa y bulbo olfactorios. Trab. Lab. Invest. Biol. Madrid, 10, 253.

(54) 1912 Nota preventiva sobre el apparato reticolar de Golgi en el embrión de pollo. Trab. Lab. Invest. Biol. Madrid, 10, 247.

(55) 1913 Alteraciones del aparato reticular de Golgi en los cellulas gigantes y altros elementos del tuberculo. Trab. Lab. Invest. Biol. Madrid, 11, 119.

(56) Fadre, Fremiet, 1910 Apropos d'une note de M. Perroncito sur le réseau de Golgi des cellules spermatiques. Bull. Soc. Zool. de France.

(57) 1910 Un appareil de Golgi dans l'oeuf de l'Ascaris megalocephala. Response a M. Perroncito. Bull. Soc. Zool. de France.

(58) FEDelr, 1912 Apparati retocolari e sarcolemma nella fibra muscolare cardiaca. Rend. d. R. Accad. d. Sc. fis. e mat. di Napoli.

(59) Fragnito, 1901 Le développement de la cellule nerveuse et les canalicules de Holmgren. Bibl. Anat., 9, 72.

(60) Gemeld, 1900 Ricerehe sperimentali sulla struttura della ghiandola pituitaria nei mammiferi. Boll. Soc. Med. Chir. di Pavia, quoted by Golgi-Arch. per le Sc. Med., 1909, 33, 5.

(61) GoLgr, 1898 Intorno alla struttura delle cellule nervose. Boll. Soc. Med. Chir. di Pavia.

1898 Arch. ital. de biol., 30, 60 . 
(62) 1898 Sulla struttura delle cellule nervose dei gangli spinali. Boll. Soc. Med. Chir. di Pavia. Arch. ital. de biol., 30, 278.

(63) 1900 Di nuova sulla struttura delle cellule nervose dei gangli spinali. Boll. Soc: Med. Chir. di Pavia.

1899 Arch. ital. de biol., 31, 273.

(64) 1900 Intorno alla struttura delle cellule della corteccia cerebrale. Verh. Anat. Ges. Pavia, 164.

(65) 1909 Sulla struttura delle cellule nervose della corteccia del cervello. Boll. Soc. Med. Chir. di Pavia, 23, 341.

(66) 1908 Une méthode pour la prompte et facile démonstration de l'appareil reticulaire interne des cellules nerveuses. Arch. ital. de biol., $49,269$.

(67) 1909 Di una minuta particolarita di struttura dell' epitelio della mucosa gastrica ed intestinale di alcuni vertebrati. Arch. per le Sc. Med., 33, 1.

1909 Boll. della Soc. Med. Chir. di Pavia, 1.

(68) Heidenhain, M. 1900 Ueber die Centralkapseln u. Pseudochromosomen in den Samenzellen. Anat. Anz., 18, 513.

(69) Henschen, 1904 Ueber Trophospongienkanälchen sympatischer Ganglienzellen beim Menschen. Anat. Anz., 24, 385.

(70) Hirschler, 1912 Ueber die Plasmastrukturen (Mitochondrien, Golgi' scher Apparat'u. A.) in den Geschlechtszellen der Ascariden (Spermato- u. Ovogenese). Arch. d. Zellforschung, 9, 351.

(71) 1914 Ueber Plasmastrukturen (Golgi'sche Apparat, Mitochondrien, u. A.) in den Tunikaten, Spongien und Protozoenzellen. Anat. Anz. $47,289$.

(72) Holmgren, 1899 Zur Kenntniss d. Spinalganglienzellen v. Lophius piscatorius. Anat. Hefte, 12, 71.

(73) 1899 Zur Kenntniss der Spinalganglienzellen des Kaninchen's u. des Frosches. Anat. Anz., 16, 161.

(74) 1899 Weitere Mittheilungen über den Bau der Nervenzellen. Anat. Anz., 16, 388.

(75) 1900 Noch weitere Mittheilungen über den Bau der Nervernzellen verschiedener Tiere. Anat. Anz., 17, 113.

(76) 1900 Studien in d. feineren Anatomie d. Nervenzellen. Anat. Hefte, $15,7$.

(77) 1900 Von den Ovocyten der Katze. Anat. Anz., 18, 63.

(78) 1902 Beiträge z. Morphologie d. Zelle. I. Nervenzellen. Anat. Hefte, 18, 269.

(79) 1902 Einige Worte über das 'Trophospongium' verschiedene Zellarten. Anat. Anz., 20, 433.

(80) 1902 Weiteres über das Trophospongium d. Nervenzellen u. der Drüsenzellen des Salamanderpankreas. Arch. f. Mikr. Anat., 60, 669.

(81) 1902 Ueber die Trophospongien d. Darmepithelzellen, nebst. eine Bemerkung in Betriff seiner v. Prof. Browicz neulich publizierten Abhandlung über die Leberzelle. Anat. Anz., 21, 477.

(82) 1903 Ueber die Saftkanälchen der Leberzellen u. der Epithelzellen der Nebenniere. Anat. Anz, 22, p. 9. 
(83) 1903 Ueber die 'Trophospongien' d. Nebenhodenzellen und die Lebergangzellen v. Helix pomatia: Anat. Anz., 20, 83.

(84) 1902 Beiträge zur Morphologie d. Zelle. Ergebn. d. Anat. u. Entw., 11,274 .

(85) 1903 Weiteres über die 'Trophospongien' der Leberzellen u. der Darmepithelzellen. Anat. Anz., 22, 313.

(86) 1903 Einige Wörter zu der Mittheilung v. Kiopsch: "Die Darstellung des Binnennetzes in spinalen Ganglienzellen u. andere Körperzellen mittelst Osmiumsaure." Anat. Anz., 22, 374.

(87) 1903 Weitere Mittheilungen über die 'Trophospongienkanälchen' d. Nebennieren vom. Igel. Anat. Anz., 22, 476.

(88) 1903 Ueber die sogenannten 'intrazellularen Fäden' der Nervenzellen von Lophius piscatorius. Anat. Anz., 23, 37.

(89) 1903 Weiteres über die Trophospongien verschiedene Drüsenzellen. Anat. Anz., 23, 289.

(90) 1904 Ueber die Trophospongien der Nervenzellen. Anat. Anz., 24,225 .

(91) 1904 Beiträge z. Morphologie der Zelle. Il. Verschiedene Zellarten. Anat. Hefte, 25, 99 .

(92) 1904 Ueber die Trophospongien Centraler Nervenzellen. Arch. f. Anat. u. Phys., 15, Anat. Abt.

(93) 1905 Zur Kenntniss der Zylindrischen Epithelzellen. Arch. f. Mikr. Anat., 65, 280.

(94) 1907 Ueber die Trophospongien der Quergestreiften Muskelfasern nebst. Bemerkungen über den allgemeinen Bau dieser Fasern. Arch. f. Mikr. Anat., 71, 165 .

(95) 1910 Untersuchungen über die morphologische nachweisbaren stofflichen Umsetzungen der quergestreiften Muskelfasern. Arch. f. Mikr. Anat., 75, 240.

(96) 1915 Die Trophospongien spinaler ganglienzellen. Arch. f. Zool. (Scandinavian), 9 (Hft. 2, Art. 15).

(97) Hortega, 1914 Alteraciones del sistema nervioso central en un caso de moquillo de forma paralitica. Trab. Lab. Invest. Biol., 12, 97.

(98) JAwonowsky, 1902 'Apparato reticolare interno' von Golgi in Spinalganglienzellen d. niederen Wirbeltiere. Bull. Acad. Sc. Cracovie, 403.

(99) Korransky, 1904 Ueber eigentümliche Gebilde in d. Leberzellen d. Amphibien. Anat. Anz., 25, 435.

(100) Kolmer, 1916 Ueber einige mit der Ramon-y-Cajal'sche Uransilbermethode darstellbaren Strukturen u. deren Bedeutung. Anat. Anaz., $48,506,529$.

(101) Kolossow, 1902 Zur Anatomie und Physiologie d. Drüsenepithelzellen. Anat. Anz., 21, 226.

(102) Korster, 1913 Ueber die durch Golgi's Arsenik- u. Cajal's Urannitratsilber Methode darstellbaren Zellstrukturen. Verh. d. Anat. Ges. Greifswald.

(103) Korsch, 1902 Die Darstellung des Binnennetzes in spinalen Ganglienzellen $u$. anderen Körpenzellen mittelst Osmiumsaure. Sitzungsber. d. k. preuss. Akad. d. Wiss., 40, 1. 
(104) Kulesch, 1914 Der Netzapparat v. Golgi in den Zellen des Eierstockes. Arch. f. Mikr. Anat., 84, 142.

(105) Kulikowska, 1911 Ueber d. Golgi-Kopschen Apparat. in den Nervenzellen der Insekten. Festschr. f. J. Nussbaum.

(106) La Valette St. George, 1886 Spermatologische Beitrage. Arch. f. mikr. Anat., 27, 1.

(107) Legendre, 1910 Recherches sur le réseau interne de Golgi des cellules nerveuses des ganglions spineaux. Anat. Anz., 36, 207.

(108) 1905 De la nature pathologique des canalicules de Holmgren des cellules nerveuses. Comptes rendues Soc. Biol., 687.

(109) Leschke, 1914 Untersuchungen über den Mechanismus der Harnabsonderung in der Niere. D. Arch. f. Klin. Med., 81, 14.

(110) Lewis, M. R., AND Lewis, W. H., 1915 Mitochondria (and other cytoplasmic constituents) in tissue cultures. Am. Jour. Anat., 18, 339.

(111) Lugaro, 1900 Sulla patologie delle celluli dei gangli sensitivi. Riv. di Pat. Nerv. e ment., 5, 145.

(112) Lucioni, 1909 Contributo allo studio dei nevi molli. Arch de Sc. Med., 33, 21.

(113) Lund, 1911 Sulla fina struttura della fibre muscolare cardiaca. Arch. f. Zellforsehung, 6,383 .

(114) 1914 Sulla fina struttura delle cellule endotheliali dell' endocardio e delle cellule que tappezano .le fendituri di Henle. Arch f. Zellforschung, 12,513

(115) MaCCABrUni, 1909 Sulla fina struttura dei Megacariociti. Boll. Soc. Med. Chir. di Pavia, 57.

(116) 1910 I Megacariociti. Intern. Monatschr., 27, 477.

(117) Marcora, 1908 Di una fina alterazione delle cellule nervose de nucleo d'origine del grande ipoglosso, consecutiva allo strappamento ed al taglio del nervo. Boll. Soc. Med. Chir. di Pavia, 22, 134.

(118) 1910 Sull' alterazione dell' apparato reticolare interno delle cellule nervose motrici consecutivi à lesioni dei nervi. Riv. di Pat. nerv. e ment., 15, 393.

1910 Arch. ital. de biol., 53, 346.

(119) 1909 Sui rapporti tra apparato reticolare interno e corpi di Nissl negli elementi nervosi. Boll. Soc. Med. Chir. di Pavia.

(120) MarenghI, 1903 Alcune particolarità di struttura e di innervazione delle cute dell' ammocoetes branchialis. Ztschr. f. wiss. Zool., 75, 421 .

(121) Martinotri, 1899 Sur quelques particularités de structure des cellules nerveuses. Arch. ital de biol.; 32, 293.

(122) 1904 Contributo allo studio dell' apparato reticolare nei muscoli striati di alcuni mammiferi. Giorn. Accad. med. Torino, 67, 639.

(123) Massenti, 1914 L'apparato reticolare interno del Golgi nel germe dentale. Monit. zool. Ital., 25, 107.

(124) Misch, 1903 Das Binnennetz der spinalen Ganglienzellen bei verschiedenen Wirbeltieren. Intern. Monatsch. f. Anat. u. Phys., 20, 329.

(125) Moriani, 1901 Di un apparato reticolare entre alcune cellule cancerique. Atti della R. Accad. dei Fisioer. di Siena fasc. 6. 
1904 Ueber ein Binnennetz der Krebszellen. Ziegler's Beiträge, 35,629 .

(127) Monti, 1915 I condriosomi e gli apparati di Golgi nelle cellule nervose. Arch. ital. di anat. e di embr., 14, 1.

(128) Mulon, 1912 Apparato reticolare et mitochondries dans la surrenale du hérisson. Comptes rend. Soc. Biol. Paris, 268.

(129) NANSEN, 1886 The structure and combinations of the histological elements of the central nervous system. Bergens Mus. Aarsberetning. (Quoted by v. Bergen).

(130) NegRI, 1900 Ueber die feinere Struktur der Zellen mancher Drüsen bei den Säugetieren. Verh. Anat. Ges. Pavia, 178.

(131) 1900 Di una fina particolarita di struttura delle cellule di alcune ghiandole dei mammiferi Boll. Soc. Med. Chir. di Pavia, 1, 61.

(132) NeLis, 1899 Un nouveau détail de structure du protoplasme des cellules nerveuses (état spirémateux du protoplasme). Bull. acad. R. Belgique, Cl. Sc., Ser. 3, T. 37.

(133) Nussbaum, 1913 Ueber die sogenannten inneren Golgi'schen Netzapparat $u$. seine Verhältnisse zu den Mitochondrien, Chromidien, u. andere Strukturen im Tierreiche. Arch. f. Zellforsehung, 10, 359.

(134) Oppenheim, 1912 Die Nervenzelle, ihr feinerer Bau u. seine Bedeutung. Anat. Anz: 41, 271.

(135) Pensa, 1899 Sopra una fina particolarità di struttura di alcuni cellule delle capsule soprarenali. Boll. Soc. Med. Chir. di Pavia, No. 2.

(136) 1901 Osservazione sulla struttura della cellule cartilagines. Boll. Soc. Med. Chir. di Pavia, No. 3/4, 119.

1901 Rend. d. R. Inst. Lomb. de Se. e Lett., Ser. ii., 34, 443.

(137) 1913 La struttura della cellula cartilaginea. Arch. f. Zellforschung., $11,557$.

(138) Perroncito, 1908 Condriosomi, cromidi. ed apparato reticolare interno delle cellule spermatiche (Nota preventiva), Rendiconti R. Inst. Lombardi., Ser. 2., 41.

(139) 1909 Contributo allo studio della biologia cellulare. Il fenomeno dello dictiocinesi. Atti Soc. ital. di patologia, 6 .

(140) 1910 Mitocondrii, cromidi ed apparato reticolare interno dello cellule spermatiche. Atti. Accad. dei Lincei., Ser. 5, 7.

(141) 1911 Beiträge zur Biologie der Zelle (Mitochondrien, Chromidien, Golgi'schen Binnennetz in den Samenzellen (Autoreferat). Arch. f. Mikr. Anat. 257, 311.

(142) 1913 Mitochondries et appareil reticulaire interne. (Apropos d'une publication de J. Duesberg.) Anat. Anz., 44, 69.

(143) 1913 A proposito di un articolo di S. Comes sulla dittocinesi. Anat. Anz., 44, 78 .

(144) Pilat, 1912 Der intracellulare Netzapparat in den Epithelzellen der Nebenniere vom Igel Erinaceus europeus. Arch. Mikr. Anat., 80, 157.

(145) Platner, 1889 Beiträge zur Kenntniss der Zelle u. ihrer Teilungserscheinungen. Arch. f. mikr. Anat., 33, 125, 108. 
(146) Polnezynski, 1911 Untersuchungen über dem Golgi-Kopsch'en Apparat $u$. einige andere Strukturen in den Ganglienzellen d. Crustaceen. Bull. Acad. Se. Gracovie, 104.

(147) Popoff, 1906 Zur Frage der Homologisierung des Binnennetzes d. Ganglienzellen mit. den Chromidien. Anat. Anz., 29, 249.

(148) REinKe, 1906 Ueber die Beziehungen d. Wanderzellen zu d. Zellbrücken, Zell-lücken u. Trophospongien. Anat. Anz., 28, 369.

(149) Retzius, 1901 Ueber Kanälchenbildung in den Riesenzellen des Knochen-markes. Verh. Anat. Ges. Bonn., 92.

(150) RIQUiER, 1910 L'involuzione dell' apparato reticolare interno nelle cellule dello corpo luteo. Boll. Soc. Med. Chir. di Pavia, 24, 185.

(151) 1913 L'apparato reticolare interno. Rivista critico-sintetica. Riv di patologia nerv. e ment., 18, 314.

(152) 1910 Der innere Netzapparat in den Zellen des Corpus luteum. Arch. f. Mikr. Anat., 75, 772.

(153) Ross 1915 The trophospongium of the nerve-cell of the crayfish (Cambarus), Jour. Comp. Neur., 25, 523.

(154) Rossi 1912 L'apparato reticolare endocellulare di Golgi. Perugia, 8vo. (Abstracted in Anat. Anz., 1912, 44.)

(155) SANCHEZ, 1907 L'appareil reticulaire de Ramon-y-Cajal-Fusari des muscles strieés. Trab. Lab. Invest. Biol., Madrid, 5, 154.

(156) SAN GIORGI, 1909 Sull' apparato reticolare interno di Golgi nel epitelio renale in condizioni patologico-sperimentali. Giorn. della R. Accad. di Med. di Torino, 15, 340.

(157) Savagnone, 1910 Sur le réseau interne de Golgi dans les cellules des tumeurs. Arch. ital. de biol., 53, 1.

1909 Also Lo Sperimentale, 63, 574.

(158) 1910 Das Golgi'sche Binnennetz in Geschwulstzellen. Virch. Arch. 201,275 .

(159) Schmincke, 1903 Zur Kenntniss d. Drüsen der menschlichen Regio respiratoria. Arch. Mikr. Anat., 61, 233.

(160) Schmads U. Bohm, 1898 Ueber einige Befunde in d. Leber bei experimenteller Phosphorvergiftung $u$. Strukturbilder von Leberzellen. Virch. Arch., 152, 261.

(161) Sinigaglia, 1910 Osservazioni sulla struttura dei globuli rossi. Arch. pi Sci. Med., 34.

(162) Suövalu, 1901 Ueber die Spinalganglienzellen des Igels. Anat. Hefte., $18,239$.

(163) 1906 Ueber Spinalganglienzellen u. Markscheiden. Zugleich ein Versuch die Wirkungsweise der Osmiumsaure zu analysieren. Anat. Hefte, 30, 259.

(164) 1906 Ein Versuch das Binnenetz von Golgi-Kopsch bei der Spermato- und Ovogenese zu homologisieren. Anat. Anz., 28, 561.

(165) v. SMIRNow, 1901 Einige Beobachtungen über d. Bau der Spinalganglienzellen bei einem 4-monatlichen mensehlichen Embryo. Arch. f. Mikr. Anat., 59, 459 .

(166) 1906 Ueber die Mitochondrien u. den Golgi'schen Bildungen analogen Strukturen in einigen Zellen v. Hyacinthus orientalis. Anat. Hef te, $32,143$. 
(167) Sovkimanoff, 1901 Rćseau endocellulaire de Golgi dans les éléments nerveaux des ganglions spinaux. Rev. neurol., 1228.

(168) 1903 Sur le réseau endocellulaire de Golgi dans les ćléments nerveaux de l'écorce cérébrale. Le Névraxe, 4.

(169) Stropeni, 1908 Sopra una fina particolarità di struttura delle cellule epatiche. Boll. Soc. Med. Chir. di Pavia, 22, 146.

(170) Studnička, 1899 Ueber das Vorkommen v. Kanälchen u. Alveolen im Körper der Ganglienzellen. Anat. Anz, 16, 397.

(171) TADDEI, 1910 Sull' apparato reticolare interno di Golgi negli elementi epiteliale della prostata ipertrofica. Lo Sperimentale, 64, 434.

(172) Tello, 1913 El reticulo de Golgi en las celulas de algunos tumores y en las del granuloma experimental prodicios por el Kiesel guhr. Trab. Lab. Invest. Biol., Madrid, 11, 146.

(173) Terni, 1914 Condriosomi, idiozoma e formazioni peri-idiosomiche nella spermatogenessi degli amfibii (Ricerche sul Geotriton fuscus). Arch. f. Zellforschung, 12, 1 .

(174) Torsuka, 1902 Ueber die Centrophormien in dem Descemets'schen Epithel des Rindes. Intern. Monatschr. f. Anat. u. Phys., 19, $\mathrm{H} 1 / 2,68$.

(175) Vastarinr-Cresi, 1903 Trophospongium e canalini di Holmgren nelle cellule luteiniche die mammiferi. Anat. Anz., 24, 203.

(176) VECCHI, 1909 Di una fina paricolarità di struttura della cellula cartildeciduale. Anat. Anz., 34, 224.

(177) Veratti, 1909 Sulla fina struttura delle celluli d di alcuni tumori. Boll. Soc. Med. Chir. di Pavia, 34 .

(178) 1902 Recherche sulla fina struttura della fibra muscolare striata. Rend. 1st. Lomb. di Scienze e Letter, 19, 6.

(179) Verson, 1908 Contributo allo studio delle cellulo giganti tubercolare e di altri elementi cellulare normali e pathologici. Arch. per le Sc. Med., 32, 489.

(180) WEIGL, 1912 Vergleichende-zytologische Untersuchungen über den Golgi-Kopsch'en Apparat u. dessen Verhältniss zu anderen Strukturen in d. Somatischenzellen, Geschlechtszellen verschiedenen Tieren. Bull. Acad. Sc. Cracovie, 417.

(181) 1910 Studien über den Golgi-Kopsch'en Apparat u. die Trophospongien Holmgrens in d. Nervenzellen d. Wirbeltiere. Wiss. Arch. 1.

(182) WigERT UND EkBERG, 1903 Ueber binnenzellige Kanälchenbildungen gewisser Epithelzellen d. Froschnieren. Anat. Anz., 22, 364.

(183) 1903 Studien über das Epithel gewisser Teile der Nierenkanäle von Rana esculenta. Arch. Mikr. Anat., 62.

(184) ZaWARzIN, 1909 Beobachtung an dem Epithel der Descemet'schen Membran. Arch. f. Mikr. Anat., 74, 116. 